\title{
The Optical characteristics of chemical bath deposition of CdS thin film
}

M. M. younis N. Y. Jamil

Department of Physics / College of Science University of Mosul
A. W. Qasm

Technical College

Mosul

\section{Received \\ $15 / 11 / 2008$}

Accepted

06 / 04 / 2009

\section{ملخص البهث}

لقد مق لستخده الطريقة الكيمياوية لتحضير أغشية كبريتات الكاميوم بلستخدلم كلوريد

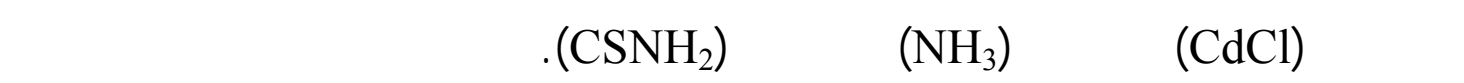

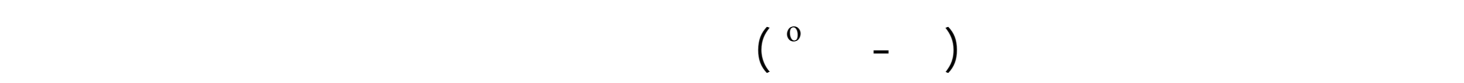

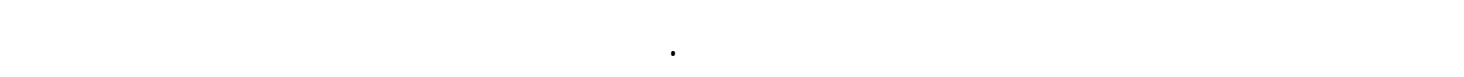

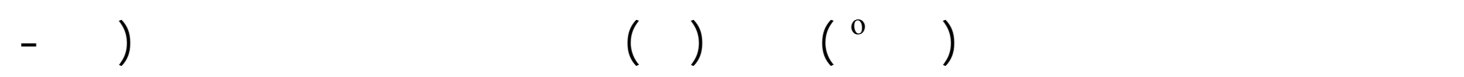

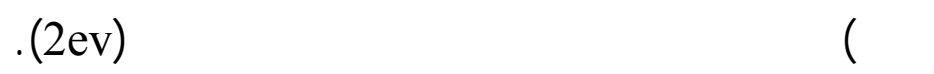

\section{Abstract :}

Chemical method has been used to prepare cadmium sulphide films by using cadmium chloride $(\mathrm{CdCl})$, Amonia $\left(\mathrm{NH}_{3}\right)$ and thiourea $\left(\mathrm{CSNH}_{2}\right)$. The effect of the temperature of preparing solution over the range of $\left(40-80^{\circ} \mathrm{C}\right)$ have been studied, it show that increasing of the solution temperature will increase the reaction speed and change the film color to more orange side. The optical properties over the wavelength range $(400-\mathrm{V} 00) \mathrm{nm}$ were recorded before and after annealing of prepared film at $300^{\circ} \mathrm{C}$ for $30 \mathrm{mint}$, so the calculated energy gap was about $(2 \mathrm{ev})$.

\section{Introduction :}

Several techniques have been used in the preparing of CdS thin film such as thermal evaporation, radio frequency sputtering, physical vapor deposition, pulsed Laser evaporation, molecular beam epitaxy, electro deposition, spray pyrolysis, metal organic chemical vapor 
deposition, successive ionic layer absorption reaction, screen printing and chemical bath deposition (CBD)[1-4].

Thin films of II-VI semi-conductors such as cadmium sulfide $(\mathrm{CdS})$ and zinc sulfide $(\mathrm{ZnS})$ are technologically important for their potential applications in optical coating, solid-state solar cell windows, optoelectronic devices, and light-emitting diodes[1-4].

Cadmium sulphide which is the most widely used material for $\mathrm{CdS} / \mathrm{CdTe}$ and $\mathrm{CdS} / \mathrm{Cu}_{2} \mathrm{~S}$ hetrojunction solar cell because of the fact that $\mathrm{CdS}$ has intermediate energy band gap, reasonable conversion efficiency, stability and low cost [1-5].

In this work, chemical deposition method has been used to prepared the samples of $(\mathrm{CdS})$ by using cadmium chloride $(\mathrm{CdCl}), \mathrm{Amonia}$ $\left(\mathrm{NH}_{3}\right)$ and thiourea $\left(\mathrm{CSNH}_{2}\right)$, which deposited on slides (Sail Brand cat.no.7101).

the effect of variation of chemical solution temperature on the quality of prepared thin film will be studied. Also the annealing treatments effect on the prepared films at $300^{\circ} \mathrm{C}$ for 30 mint had been studied. The fundamental optical prosperities which had been investigated here are transmittance and absorbance of light near infrared (NIR) which strongly depend on band-gap and the nature of the film material properties[1-7].

\section{Experimental method :}

The deposition reaction was slowed down therby preventing spontaneous precipitation by the use of suitable complexing ions.

Before the deposition of cadmium sulphide on glass slides, the slides (substrate) cleaned by the available cleaning detergent and washed by methanol, then rinsed with distilled water and allowed to dry in air.

The chemical that are involved in the growth of the cademium sulphide thin film are the cadmium chloride $(\mathrm{CdCl})$, ammonia $\left(\mathrm{NH}_{3}\right)$ as a complexing agent, thiourea $\left(\mathrm{CSNH}_{2}\right)$ as a means of obtaining sulphide ion in the reaction.

In the reaction bath, $2 \mathrm{ml}$ of cadmium chloride $(\mathrm{CdCl})$ solution was added in to a $50 \mathrm{ml}$ beaker, the reaction of the mixture was stirred then $5 \mathrm{ml}$ of a prepared ammonia $\left(\mathrm{NH}_{3}\right)$ added to the solution.

The mixture was stirred, after which $5 \mathrm{ml}$ of $\left(\mathrm{CSNH}_{2}\right)$ solution was measured and added in the beaker then the mixture stirred again.

The temperature of the preparing solution varied in the range of $40,60,80{ }^{\circ} \mathrm{C}$, it was found that the increasing of solution temperature during deposition will increase the orange color of these films.

The thickness of the films obtained in the range of $(4.22-7.78 \mu \mathrm{m})$ done by subtract the weight of the slid before and after the deposition then applying the usual density equation: 
$\mathrm{V}=\mathrm{m} / \rho$

Where $m$ is the weight of the film material, $\rho$ is the density of the cadmium sulphide, the thickness of the film determined from:

$$
\mathrm{t}=\mathrm{V} / \mathrm{A}
$$

where $\mathrm{t}$ is the thickness of the film, $\mathrm{V}$ is the volume and $\mathrm{A}$ is the area of the slide

The transmittance and absorbance measurements of prepared films obtained using (spectrophotometer 2000-721) for which the absorption coefficient calculated by:

$\alpha=2.303\left(\mathrm{~A}-\mathrm{A}^{\prime}\right) / \mathrm{t}$

Where $\mathrm{A}^{\prime}$ is the lowest value of absorbance on the graph [1-2].

The band gab was then obtained from the relation between the absorption coefficient and the incident photon energy for direct and allowed electronic transions cases is:

$$
\alpha=\left(\mathrm{h} v-\mathrm{E}_{\mathrm{g}}\right)^{1 / 2}
$$

When $\alpha^{2}=0$ then

$\mathrm{E}_{\mathrm{g}}=\mathrm{hc} / \lambda$

\section{Results and discussion:}

The increasing of the temperature solution during the deposition gave an increasing in the orange color of the films which mean that the cadmium sulphide concentration increasing as the solution temperature increased.

Figure(1) show the transmittance for the same film before and after annealing, it was observed that the maximum transmittance for the film decrease after annealing at $300^{\circ} \mathrm{C}$ for 30 mint.

Figure(2) show the absorbance before and after annealing, we found that the maximum absorbance increases after annealing of the film, so that, the absorption coefficient of the film will increase as we see in figure(3) and figure(4).

From figure(3), figure(4) and figure(5) we can indicate that the energy gap of the prepared films was $(r, \tau$ ev $)$

Figure(1) and figure(5) shows the comparison of transmittance and absorption coefficient before and after annealing, which indicts the effect of annealing of the films will decrease the transmittance and increase the absorption coefficient of the prepared films. this is explained due to forming a single grain instead all initially grown grains, in other words because of reduction of grain boundaries which could help in transmittance.

The increase in the absorbance of the films in wavelength range (450-490 nm) it might be due to presence of a center in the energy gap generally its value is lower than the band gap energy value which causes increase in the transmittance curve on a peak. 


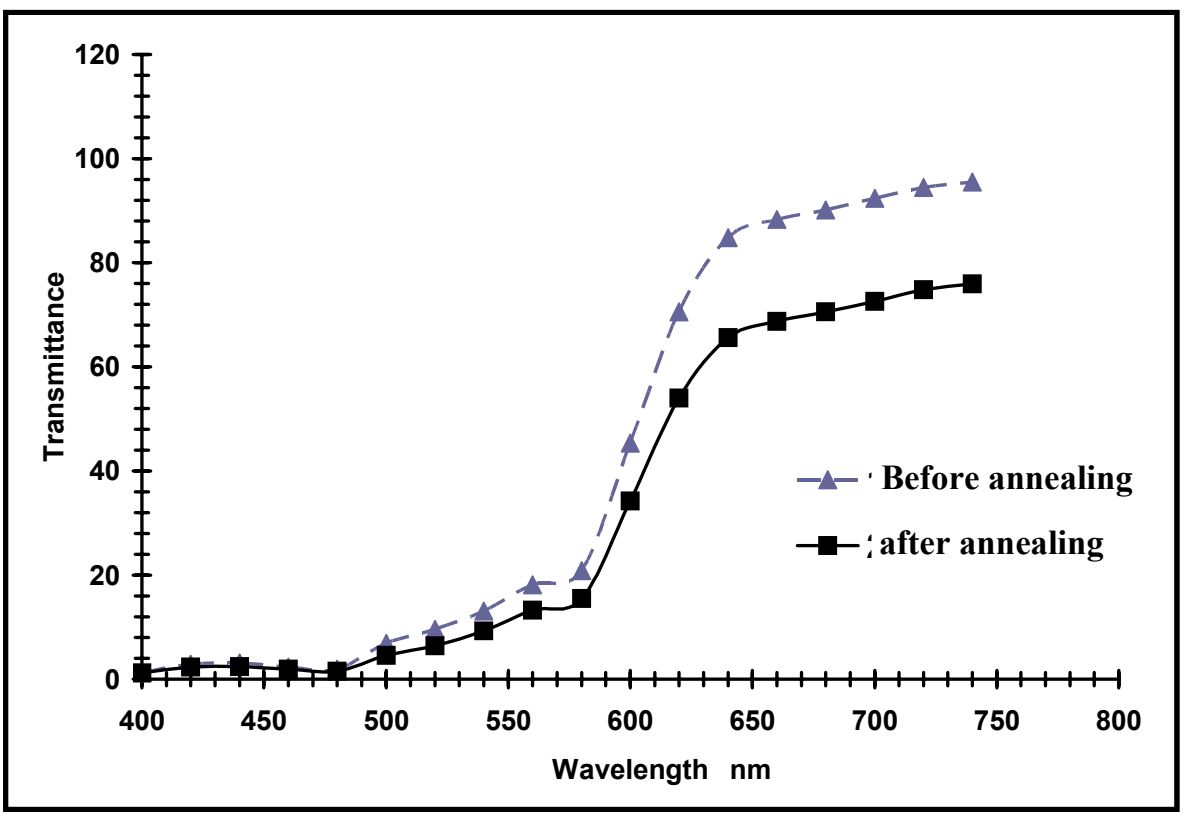

Figure(1): comparing between the transmittance before and after annealing at $300^{\circ} \mathrm{C}$ for $30 \mathrm{mint}$

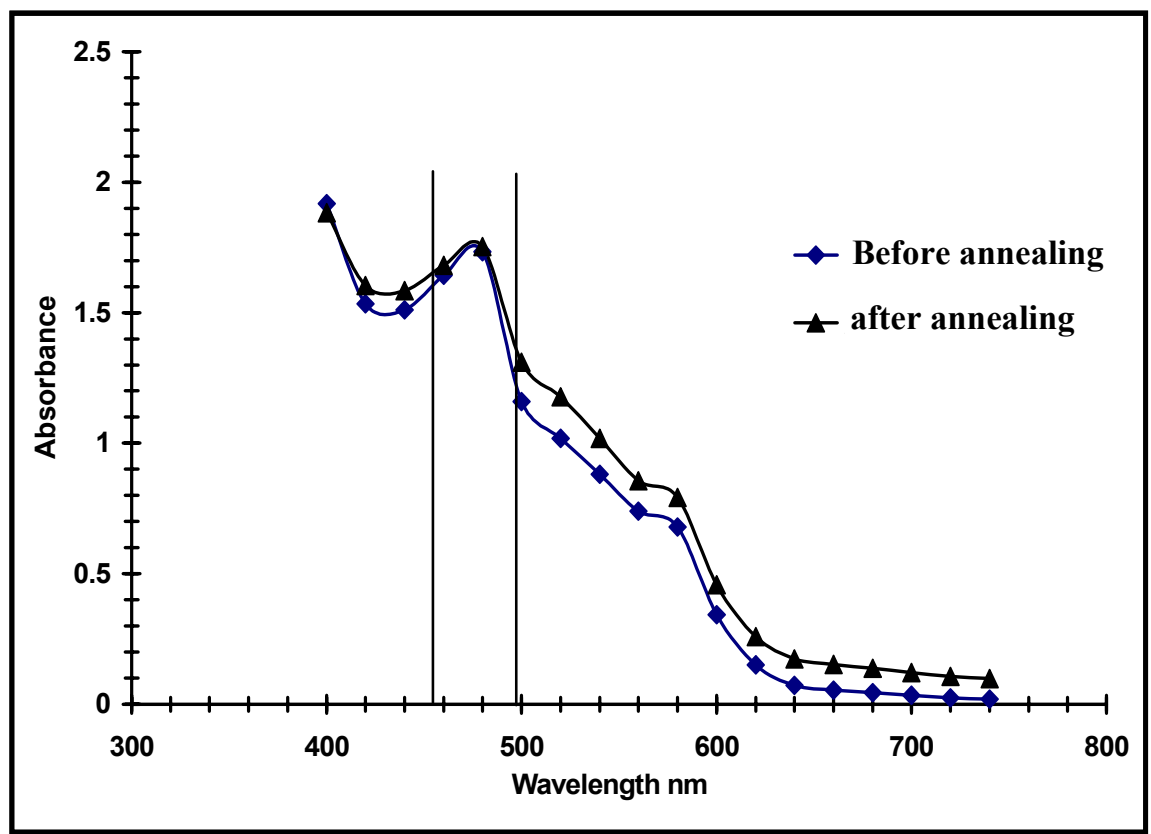

Figure(2): comparing between the absorbance before and after annealing at $300^{\circ} \mathrm{C}$ for $30 \mathrm{mint}$ 


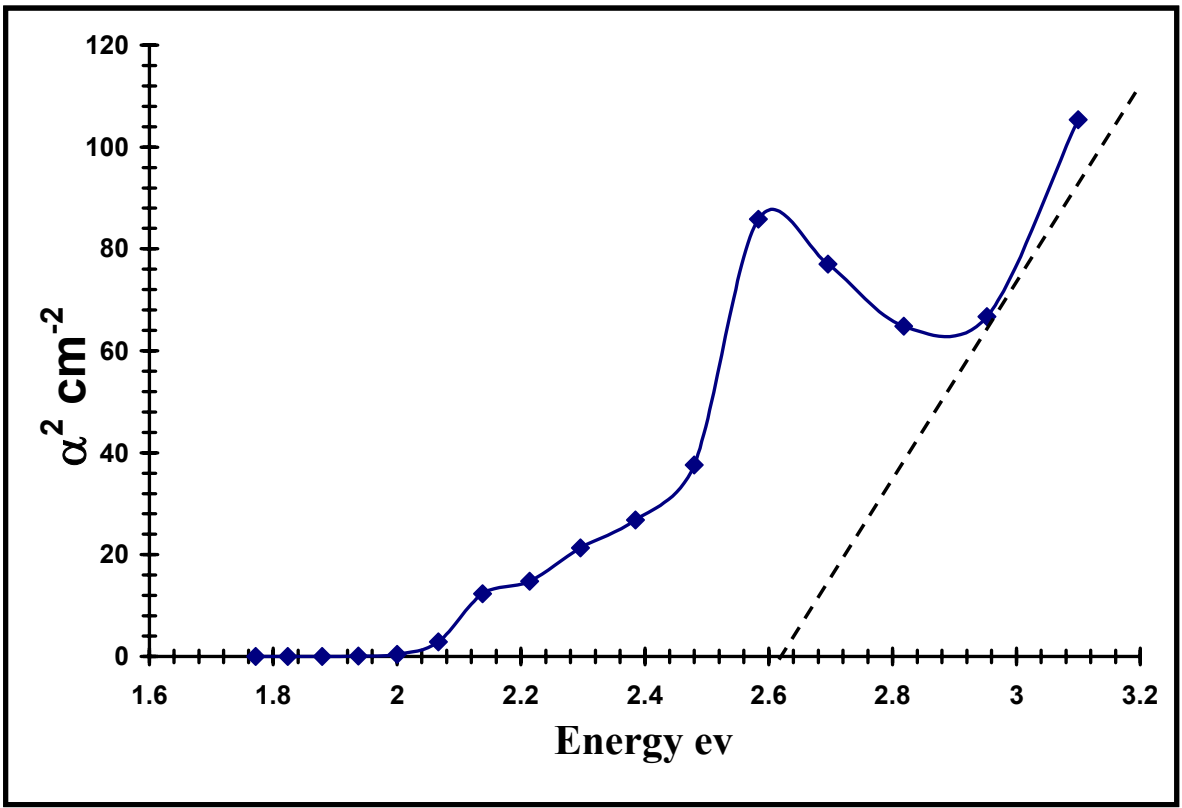

Figure(3): the absorption coefficient as a function of energy before heating

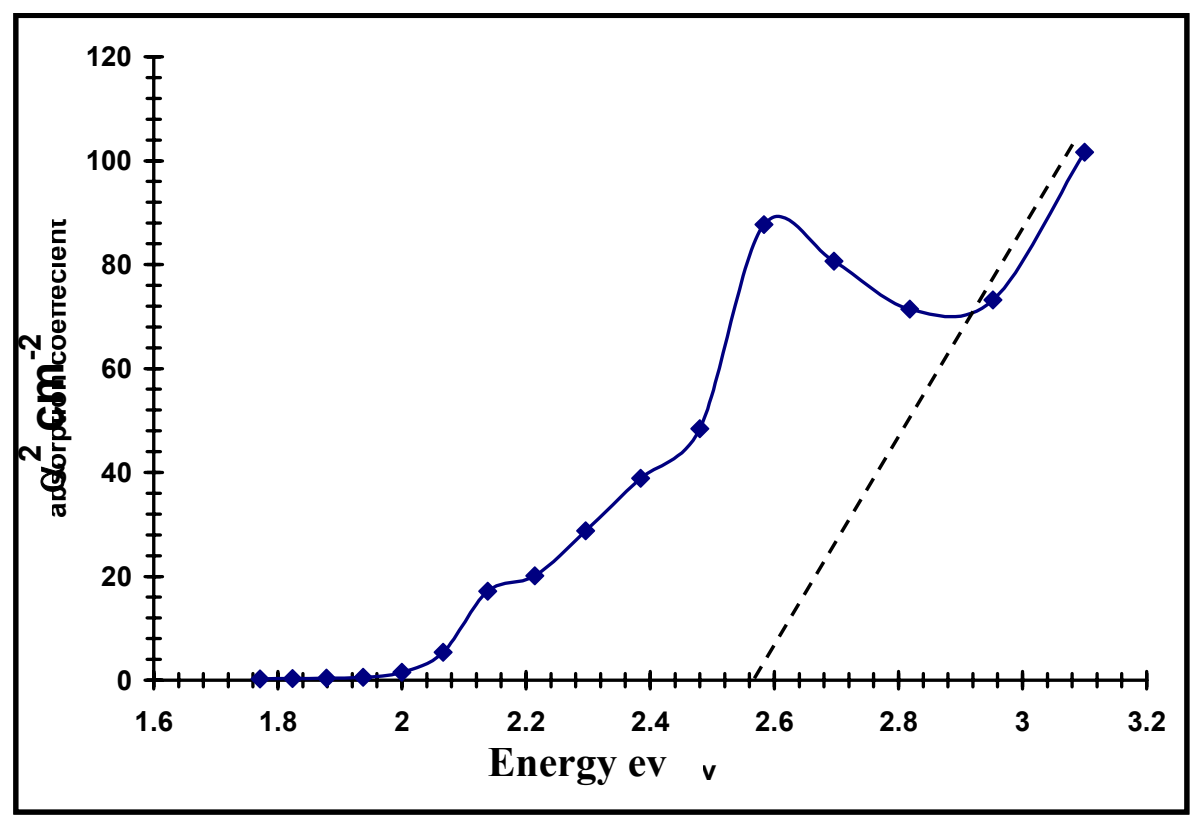

Figure(4): the absorption coefficient as a function of wavelength after heating 


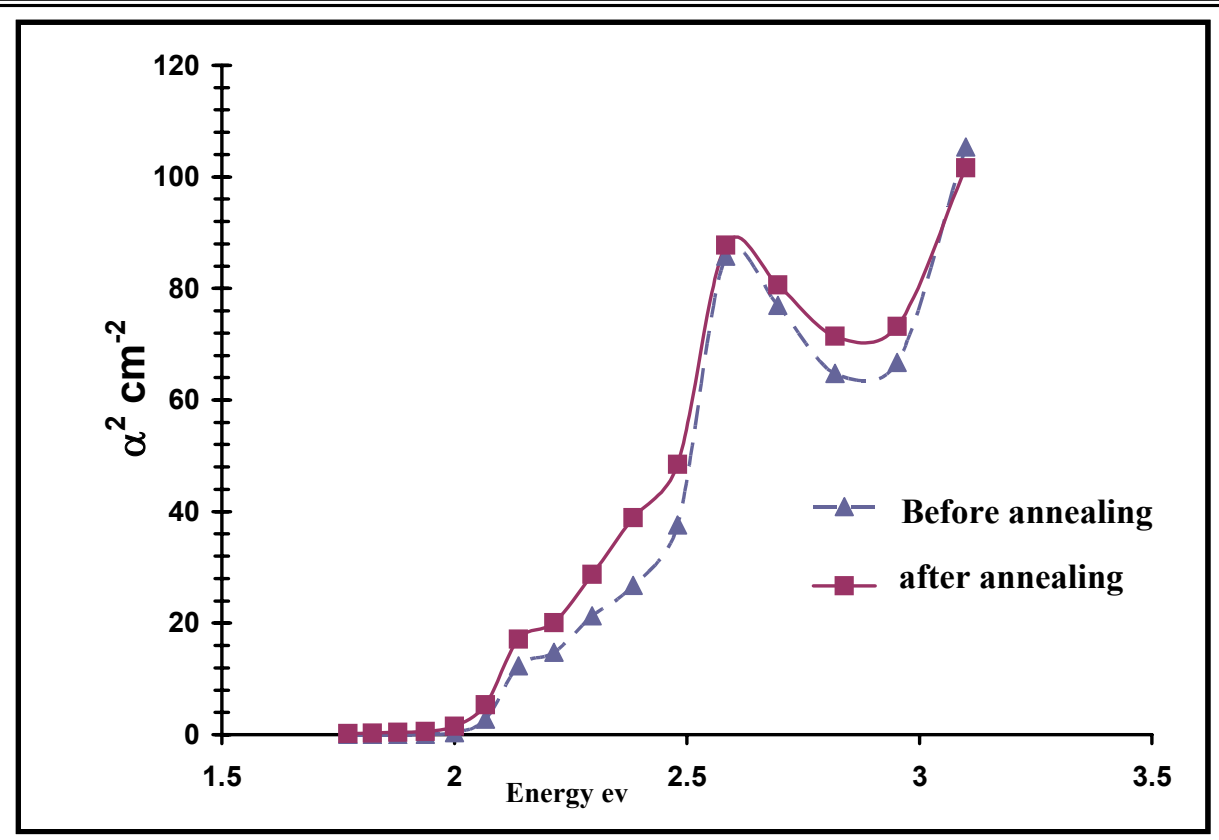

Figure(5): comparing between the absorption coefficient before and after annealing at $300^{\circ} \mathrm{C}$ for $30 \mathrm{mint}$

\section{References :}

1) PATIDAR D., SHARMA R., JAIN N., SHARMA T. P. and SAXENA N. S., (2004) "Optical properties of CdS sintered film", Bull. Mater. Sci., Vol. 29, No.1 pp. 21-24.

2) Ugwu E. I. and Onah D. U., (2007), "Optical Characteristics of Chemical Bath Deposited CdS Thin Film Characteristics within UV, Visible, and NIR Radiation", Pacific Journal of Science and Technology, Vol. 8. Number 1.

3) ASHOUR A., (2003) "Physical Properties of Spray Pyrolysed CdS Thin Films", Turk. J. Phys., vol.27 p. 551 - 558.

4) Hani Khallaf a., Isaiah O. Oladeji b., Lee Chow a., (2007), "Optimization of chemical bath deposited CdS thin films using nitrilotriacetic acid as a complexing agent", Thin Solid Films, Vol.10 p. 079

5) Archbold M. D., Halliday D. P., Durose K., Hase T. P. A., SmythBoyle D., Govender K., (2005), "Characterization Of Thin Film Cadmium Sulfide Grown Using a Modified Chemical Bath Deposition Process",IEEE Electron Devices Society,JANUARY 3-7.

6) A. V. Feitosaz, M. A. R. Miranday, J. M. Sasakiy, and M. A. Ara'ujo-Silvaz, (2004) "A New Route for Preparing CdS thin Films by Chemical Bath Deposition Using EDTA as Ligand", Brazilian Journal of Physics, June vol. 34, no. 2B

7) VAZQUEZ LUNA J. G, ZEHE A., ZELAYA-ANGEL O., (1999), "Chemical CdS Thin-Film Deposition Influenced by External Electric and Magnetic Fields", Cryst. Res. Technol., Vol.24 N.8 p. 949-958. 